\title{
Belgian Cardiological Society
}

Meeting of January 13th, 1952

Carvalho (Buenos Aires): Arterial systolic hypertensive cases cured after trauma.

Clinical description of two cases of systolic hypertension spontaneously cured after serious trauma (skull and bone fractures). Pathogenic discussion and distinction between the splanchnopathy (reversible) and the arteriolopathy (irreversible).

J. Lequime, H. Denolin, and A. Verniory: One case of Paget's disease and study of its circulation.

The authors summarize the work of McMichael who studied the circulation in cases of generalized and localized Paget's disease. In this case no cardiac insufficiency was present; the ecg, the intracardiac pressures, the cardiac output were normal, as well as the peripheral resistance.

In the upper limbs (where no Paget lesions were present) an elevated arteriovenous difference was found and the opposite in the lower limbs. These local circulatory changes have no effect on the general circulation although this case of Paget's disease is nearly generalized.

188

Belgian Cardiological Society

M. Segers, O. van Houte, M. Brombart, and Y. Laurent: The influence of congenital or acquired diseases of the aorta on the deviations of the esophagus.

Radiological study of aortic elongation (unwinding) and corresponding deviations of the esophagus. The esophagus follows the aorta in 60 to $70 \%$ of the cases. In $50 \%$ of the cases an esophageal diverticulum is seen. in certain sclerotic diseases of the aorta the authors note adhesions between the esophagus and the inferior surface of the aortic arch. In $10 \%$ of the cases with esophago-aortic "unwinding", an intrathoracic gastric hernia is noted. Descending aortas with supra-diaphragmatic tortuosities may produce a peculiar deviation of the esophagus showing the picture of a sickle (this position of the esophagus is likely to change suddenly owing to the heart beats). In cases where the descending aorta is tortuous and deviated to the right side, no displacement of the esophagus was noted.

Several other slides show cases of double aorta, aberrant insertion of the right subclavian artery, patent ductus arteriosus and coarctation of the aorta and the impressions made by these structures on the esophageal surface.

jR. Stas, P. Soulié, and M. Servelle: Mitral disease and valvulotomy.

The authors present the results of surgical treatment in 38 cases of mitral disease (mortality: two cases). Hemodynamic studies by means of catheteriza-tion were performed and the pressures were measured in the different parts of the pulmonary artery; this leads to discussion of the pulmonary oedema.

The best cases to operate on are patients between 20 and 35 years, with sinus rhythm, arterial pulmonic hypertension and small mitral "surface". Surgical treatment is not advisable when there is cardiac insuffiency and pulmonary arteritis. 
In the post-operative course, a decrease of the preexisting mitral regurgitation is sometimes noted, the pressure in the pulmonary artery reaches normal values sometimes only after several months. C. M. Callebaut.

Buchbesprechungen - Book Reviews - Livres Nouveaux

ö, Ritter und V. Fattorusso: Atlas der Elektrokardiographie. S. Karger AC, Basel 1951. 256 Seiten, 219 Abb., sFr. 36.40.

Der «Allas der Elektrokardiographie* von O. Ritter und V. Fattorusso er-füllt die Aufgabe, die sich die Autoren gestellt haben, «eine Einführung in die klinische Elektrokardiographie für Studenten und Ärzte zu schaffen».

Der Text ist angenehm knapp gehalten, durch zahlreiche typische Beispiele illustriert. Das Buch eignet sich gut zum Selbststudium und kann, da es voraus-setzungslos beginnt, auch von Ärzten, denen das Gebiet bisher fern lag, zur Einführung in die Elektrokardiographie mit Vorteiî benützt werden. Es wirkt nicht schon zum vorneherein durch großes Volumen prohibitiv. 